\title{
OPPORTUNITY OF IMPROVING THE SPEED QUALITY OF KIDS UP TO 11 YEARS AGE, PRACTICING FOOTBALL
}

\author{
Y. Gorelski* \\ Department of Sport, Sofia University, Sofia, Bulgaria
}

\begin{abstract}
Changes in speed, length and frequency of the running stride have been taken into account with and without a ball in a football game. Differences have been observed in its structure in linear acceleration and in a game of "square",which requires a special preparation,enhancing and automating of two biomechanical indicators of speed and increasing the efficiency in a football game.
\end{abstract}

Key words: speed, students, football, methods, physical preparation

\section{INTRODUCTION}

Concepts of presence of 5 main physical qualities have been left far behind, such as speed, endurance, strength, agility and flexibility. In practice new terms have entered, distinguishing the qualities into other varieties, remaining the general nature of movement.

Specialists are in one mind that the velocity abilities are ought to be divided into:

a) time of the basic motive reaction;

b) speed of the singular contraction of a muscle;

c) frequency of movement.

According to leading specialistc, such as Zaciorski, V (1966), Zhelyazkov, Tsv (1998), Ozolin, H.G., (1949) (1-3), these varieties of speed represent different qualities and lightly correlate with one another. Other specialists look for the interdependence between the height and velocity. Peltekova, I (2018) ascertains that in average the taller trainees have shown a better result in a $20 \mathrm{~m}$ sprint run. Of course, the individual characteristics and the level of the other physical qualities have to be taken into consideration, in particular-the strength and weight contestants (4).

Correspondence to: Yusuf Gorelski, PhD student; Department of sport, Team sports and mountain sports, Sofia University, address: bul. "Tsar Osvoboditel" 15, 1504 Sofia, Bulgaria, e-mail: ussouf@abv.bg; Telephone:+359/894 307777
In relation to strength, aggregate, maximal, speed, strength and endurance have been distinguished, but later Zaciorski, V. and Smirnov (1968), Y., Verhoashanski, Y (1964), agree on the fact that strength can be subdivided into even more detailed parts, such as explosiveness, fast and slow strengths (5-6). The question of choosing methods of evolving of speed qualities in football players is an actual subject of debate between specialists, as most of them agree that speed is a genetically determined quality of the living matter and nothing major can be done to increase it. On the other hand, many practical examples indicate that if frequency of movement hardly improves, then the length of a step with the aid of strength building and speed-strength exercises is liable to significant growth. The two components, frequency and length of the running stride form the basis of the development of this quality. The definition "agility" has been brought up, often misleading in translation. Its meaning is "speed, dexterity, nimbleness, handiness". Many physical qualities have been combined into one, which toughens its elaboration with the known training ways and means.

Agility preparation is also used in many other sports games. In research of basketball players, I. Peltekova (2014 notes: "With agility preparation, the ability of the sportsman to maintain his balance in shifting situation is 
enhanced along with the speed of performance of separate motions, coordination and strength.The specificity of the basketball game as a change of functions of all players from forwards to defenders and forth require fastpaced reflexes and effective footwork from the contestants "Agility" skills provide an opportunity to change the direction of the body in a more efficient manner (7).

Enhancing speed in football players, however, is much harder as beside linear velocity, it is also required to improve the speed in which the running direction alters the rhythm of cyclic movements is violated; numerous motions take place in a restricted perimeter of action with high speed.

Physiologists Mateev, Dr. (1962), Manno, R., (1985), Zander, C., (1989) regard speed first and foremost as a function of the cortex of the cerebrum and its ability to send nerve impulses to be taken in by the motor cells, moreover with a clear shift of the processes of excitation and fret in the central nervous system (8-10).

The resources with which football deals are aimed at raising the level of the maximum speed with and without a ball. Some exercises are used close in structure with these demonstrated in the football game (11).

In a series of sports games resources and athletic methods as well as such "which successfully replace the entirely athletic training resources with such of similar intensity and continuance of the motive action as in essential football exercises (12-16).

As most widely-spread methods of increasing the speed of football players are regarded:

1. Method of repetitive strives with maximal speed, in which basic as well as more complex exercises are used;

2. Methods of enhancing the reaction in complex in-game conditions, when a decision has to be taken quickly depending on the situation;

3. Method of repetitive strives within lessened conditions (running on a slope with the aid of a traction device-sprint machine and etc.).

\section{METHODOLOGY}

The aim of our research lies in discovering training resources methods which would improve the evolution of linear, athletic as well as specific football speed when operating with a ball.

The goal of the research are:

1. Set the speed changes in running with and without a ball in different game situations.

2. Determination of the variations in the running speed depending on the changes of the main components of the speed - the length and the frequency of the bevel step in different situations.

\section{ORGANIZATION OF THE RESEARCH}

Two groups of football trainees have been formed consisting of 25 members aged up to 1: control and experimental groups. The first group applies the already known programs for the ascertained age; the second group applies a program designed by us to develop physical qualities. Training sessions are held 3 times a week in the course of 12 weeks. In the beginning and end of the experiment the same trainees are put to a test by specified from (Table 1) indicators. The data has been processed statistically.

\section{RESULTS AND ANALYSIS}

The content of the experimental models of elaborating football players' speed qualities is shown in Table 1, where the main stress of overload is predicted to be in the first and third training session, the second, on the other hand is mainly aimed at the development of sprint endurance.

After processing the results, from the second testing, an analysis of success rate has been made in both experimental and control groups The approximately equal anthropometric indexes in both groups are observed to go through insignificant changes increasing their values, which is as expected bearing in mind that the age of the football players is 10-11years-old. (Table 2)

In the speed exercises (5 and 6) the growth of the results in the experimental group is considerably higher in comparison to the control group. This is especially highlighted in index №6, where the improvement in the experimental group is $1.53 \mathrm{~s}$, while the control group is at $0.27 \mathrm{~s}$. 
GORELSKI Y.

Table 1. Content of the training model for development of the speed qualities of the students from the experimental group

\begin{tabular}{|c|c|c|c|c|}
\hline № & Training resources & $\begin{array}{l}1^{\text {st }} \text { training } \\
\text { session }\end{array}$ & $\begin{array}{l}2^{\text {nd }} \text { training } \\
\text { session }\end{array}$ & $\begin{array}{l}3^{\text {rd }} \text { training } \\
\text { session }\end{array}$ \\
\hline \multirow{3}{*}{1} & \multirow{3}{*}{$\begin{array}{l}\text { High start: } \\
\text { to } 15 \mathrm{~m} \\
\text { to } 30 \mathrm{~m}\end{array}$} & & & \\
\hline & & no & yes & no \\
\hline & & yes & no & yes \\
\hline 2 & „Rolling start” up to $20 \mathrm{~m}$ & no & yes & no \\
\hline 3 & Starts from different starting positions $(20 \mathrm{~m})$. & yes & no & yes \\
\hline \multirow{3}{*}{4} & Interval runs: & & & \\
\hline & 3 sets of $4 \times 40 \mathrm{~m}$. with $80 \%$ intensity rate & yes & no & yes \\
\hline & 2 sets of $4 \times 30 \mathrm{~m}$. with $95 \%$ intensity rate & no & yes & no \\
\hline 5 & Repetitive runs:3 sets $3 \times 20 \mathrm{~m}$. with $90 \%$ intensity rate & yes & no & no \\
\hline 6 & $\begin{array}{l}\text { Slalom runs without a ball between } 5 \text { obstacles, } 3 \text { sets } \\
3 \times 15 \mathrm{~m} \text {. with } 95-100 \% \text { intensity catch-up striving rate }\end{array}$ & yes & no & yes \\
\hline 7 & $\begin{array}{l}\text { Slalom runs with a ball between } 5 \text { obstacles, } 3 \text { sets } \\
3 \times 15 \mathrm{~m} \text {. with } 95-100 \% \text { intensity catch-up }\end{array}$ & no & yes & yes \\
\hline 8 & $\begin{array}{l}\text { Runs with a forward fetched ball } 2-3 \text { sets each } 4 \text { reps } \\
\text { within } 20-30 \mathrm{~m}\end{array}$ & yes & no & no \\
\hline 9 & „Play in a square” $(8 \times 8 \mathrm{~m}) .2 \times 8 \mathrm{~min}$ & yes & no & yes \\
\hline 10 & Speed handling of the ball between 5 obstacles & yes & no & yes \\
\hline 11 & Quick run & no & no & yes \\
\hline 12 & Speed exercises on & yes & yes & no \\
\hline \multirow{3}{*}{13} & \multirow{3}{*}{$\begin{array}{l}\text { Multi-jump: } \\
\text { a) } 3 \times 3 \text { tenfold jumps } \\
\text { b) } 5 \times 3 \text { fivefold }\end{array}$} & & & \\
\hline & & no & yes & no \\
\hline & & yes & no & yes \\
\hline 14 & $\begin{array}{l}\text { Tempo endurance. Square } 50 \times 50 \mathrm{~m} \text {.Two repetitions, in } \\
\text { two series. }\end{array}$ & no & yes & no \\
\hline \multirow[b]{2}{*}{15} & Speed endurance: & \multirow[b]{2}{*}{ no } & \multirow[b]{2}{*}{ no } & \multirow[b]{2}{*}{ yes } \\
\hline & $\begin{array}{l}3 \times 60 \mathrm{~m} \text {. sprint. Rest every } 2 \text { min. } \\
4 \times 40 \mathrm{~m} \text {. tempo run. Rest every } 30 \mathrm{~s} \\
5 \times 30 \mathrm{~m} . \text { accelerating. Rest every } 20 \mathrm{~s} \\
8 \times 15 \mathrm{~m} \text {. sprint. Rest every } 50 \mathrm{~s}\end{array}$ & & & \\
\hline
\end{tabular}

Table 2. Mean values of 1 to 8

\begin{tabular}{|l|l|l|l|l|l|l|l|}
\hline \multirow{2}{*}{ Index } & №: & Height & Weight & $\begin{array}{l}15 \mathrm{~m} \text { run } \\
\text { from a } \\
\text { high start }\end{array}$ & $\begin{array}{l}30 \mathrm{~m} \text { run } \\
\text { from a } \\
\text { high start }\end{array}$ & $\begin{array}{l}15 \mathrm{~m} \\
\text { "slalom” } \\
\text { run } \\
\text { without a } \\
\text { ball }\end{array}$ & $\begin{array}{l}15 \mathrm{~m} \\
\text { "slalom” } \\
\text { with a } \\
\text { ball }\end{array}$ \\
\hline $\mathbf{1}$ & $\mathbf{2}$ & $\mathbf{3}$ & $\mathbf{4}$ & $\mathbf{5}$ & $\mathbf{6}$ & $\mathbf{7}$ & $\mathbf{8}$ \\
\hline $\begin{array}{l}\text { Experimental } \\
\text { Group }\end{array}$ & Start & $163.5 \pm 2.3$ & $50.1 \pm 1.4$ & $3.35 \pm 0.03$ & $6.60 \pm 0.02$ & $6.72 \pm 0.09$ & $9.28 \pm 0.28$ \\
\cline { 2 - 8 } & End & $164.2 \pm 1.9$ & $50.8 \pm 1.8$ & $3.14 \pm 0.02$ & $5.07 \pm 0.05$ & $6.36 \pm 0.06$ & $8.70 \pm 0.36$ \\
\hline Control Group & Start & $164.3 \pm 2.2$ & $51.3 \pm 1.8$ & $3.41 \pm 0.03$ & $5.64 \pm 0.05$ & $6.80 \pm 0.07$ & $9,31 \pm$ \\
\cline { 2 - 8 } & End & $164.7 \pm 2.2$ & $52.0 \pm 2.4$ & $3,29 \pm 0.03$ & $5,37 \pm 0.04$ & $6,61 \pm 0.05$ & $9,04 \pm$ \\
\hline
\end{tabular}

Both indexes, characterizing the nimbleness in overcoming obstacles and handling of the ball change in the experimental group respectively by $0.36 \mathrm{~s}$ in index №7 and by $0.58 \mathrm{~s}$ in index №8.In the same tests the changes in the control group are $0.19 \mathrm{~s}$ and $0.27 \mathrm{~s}$. Juxtaposing the time required to overcome the 5 obstacles, ranged within $15 \mathrm{~m}$,each of which is distanced by $3 \mathrm{~m}$ one from the other, a fascinating result has noted. When running with and without the ball in the second group differences are smaller (from 0.08s.) in the control group, while in the experimental group the differences are $0.22 \mathrm{~s}$. We owe this to the fact that the speed of handling the ball in the experimental group $(1.72 \mathrm{~m} / \mathrm{s})$ and the control group $(1.65 \mathrm{~m} / \mathrm{s})$ to a certain extent causes a difficulty to performing 
dribble runs and lowers the effectiveness when performing the exercise.

The exercise, describing the level of the sprint endurance - „Base line running” - 4x40 m” (№9) in the control group has been improved by $1.23 \mathrm{~s}$, while the change in the experimental group is twofold to the good-2.13s. The result highlights the significant increase in the level of accumulated velocity in a linear stride of football players from the experimental group (Table 3).

Table 3. Mean values of 9 to 15

\begin{tabular}{|c|c|c|c|c|c|c|}
\hline \multirow{2}{*}{$\begin{array}{l}\text { „Base line } \\
\text { running - } 4 \\
\text { x } 40 \mathrm{~m} .\end{array}$} & \multicolumn{2}{|c|}{ Length of the stride in: } & \multicolumn{2}{|c|}{$\begin{array}{l}\text { Frequency of the stride } \\
\text { in: }\end{array}$} & \multicolumn{2}{|c|}{ Speed of run in: } \\
\hline & $\begin{array}{l}\text { „fetching” } \\
\text { of the ball } \\
(\mathrm{cm})\end{array}$ & $\begin{array}{l}\text { „Play in a } \\
\text { square” } \\
(\mathrm{cm})\end{array}$ & $\begin{array}{l}\text { Fetching of } \\
\text { the ball } \\
(\mathrm{st} / \mathrm{s})\end{array}$ & $\begin{array}{l}\text { „Play in a } \\
\text { square” } \\
\text { (st/s) }\end{array}$ & $\begin{array}{l}\text { Fetching } \\
(\mathrm{m} / \mathrm{s})\end{array}$ & $\begin{array}{l}\text { Play in a } \\
\text { square }(\mathrm{m} / \mathrm{s})\end{array}$ \\
\hline 9 & 10 & 11 & 12 & 13 & 14 & 15 \\
\hline $23.56+0.08$ & $137.2 \pm 3.7$ & $117.5 \pm 3.3$ & $3.50 \pm 2.4$ & $3.82 \pm 3.4$ & $4.80 \pm 0.17$ & $4,48 \pm 0.20$ \\
\hline $21.43 \pm 0.07$ & $136.3 \pm 2.4$ & $119.9 \pm 1.9$ & $3.72 \pm 0.9$ & $4.09 \pm 0.4$ & $5.07 \pm 1.1$ & $4.90 \pm 1.3$ \\
\hline $22.89+0,06$ & $133.1 \pm 3.1$ & $114.9 \pm 3.1$ & $3.49 \pm 1.8$ & $3.63 \pm 3.0$ & $4.64 \pm 1.6$ & $4.17 \pm 2.1$ \\
\hline $21.66 \pm 0.07$ & $136.1 \pm 3.3$ & $112.4 \pm 3.4$ & $3.53 \pm 2.1$ & $3.98 \pm 2.7$ & $4.80 \pm 1.3$ & $4.47 \pm 1.4$ \\
\hline
\end{tabular}

The changes in the speed of movement in both groups in relation to the change of its two main components, the length and the frequency of the running stride, observed in the sprint "fetching the ball laid forward" and in the game of "square" have noticeable differences. In the first case the length of the stride decreases by $0.9 \mathrm{~cm}$ and the frequency increases by $0.22 \mathrm{st} / \mathrm{s}$. These changes lead to the increase in linear speed by $0.27 \mathrm{~m} / \mathrm{s}$. These differences in the control group are respectively increased by $3.0 \mathrm{~cm}$ and $0.16 \mathrm{st} / \mathrm{s}$, thus making the reached speed $0.16 \mathrm{~m} / \mathrm{s}$, which is $0.11 \mathrm{~m} / \mathrm{s}$ faster than that of the experimental group. In the second exercise game of "square" in the experimental group we noted an increase in the length of the stride by $2.4 \mathrm{~cm}$ and increase in frequency by $0.27 \mathrm{st} / \mathrm{s}$.

This ration between the two indicators has led to the increase in velocity in movement in "square" by $0.42 \mathrm{~m} / \mathrm{s}$. In the control group the length of the stride has been decrease by $2.5 \mathrm{~cm}$, while the frequency has gone up by $0.35 \mathrm{st} / \mathrm{s}$. These results show that football players from the experimental group have a better interaction with the support in the of act acceleration in its linear values as well as in the game of "square".

\section{CONCLUSION}

1. Our put forward model shows positive results when working for qualities. The level of the researched indicators of speed with as well as without the ball have improved significantly
2. In the utilized exercises it is obligatory to have linear running sessions without a ball, in which the frequency of motion increases considerably on behalf of the length of the running stride.

3. It is compulsory to have a purposefully training work for research, elaboration and automation of the length and frequency of the running strides during accelerative run on a straight line in games within a restricted area of action.

\section{REFERENCES}

1. Zaciorski, V., Physical qualities sporty. FSC. M. pp. 22-26, 1966.

2. Zhelyazkov, Tsv., Based on the sport training. NSA. S., 1998.

3. Ozolin, H.G., Быстрота и методика её developments. TPPK, M., 7, pp. 8-12. 1949

4. Peltekova, I., Interdependence between a maximum running speed of 20 meters and the growth of students playing basketball. Tenth MNC: Contemporary Trends in Physical Education and Sport. IM "St. Kliment Ohridski ", S., 2018, ISSN 13142275, pp. 280-285, 2018.

5. Zaciorski, V. and Smirnov, Y. Impact gradient power on result speed-force moves. CFPC. M. pp.8-12, 1968.

6. Verhoashanski, Y., New in silhouetting preparation. Athletics, M., pp. 8-12, 1964.

7. Peltekova, I. Sports basketball training of student teams. Monograph, ISBN 978-95407-3680-8, "St. Kliment Ohridski ", www.unipress.bg, pp. 106; S., 2014. 
8. Mateev, Dr., Physiology of muscle fatigue and ultimate effort. Sp. VFK. 7, pp.10-13, 1962.

9. Manno, R., Valutazione della capicita motoria di giovani atleti. Rivista di cultura sportiva, 1, pp. 49-52, 1985.

10.Zander, C., Physiological considerations in the training of young athletes. Sports Med, 8, pp. 15-20, 1989.

11.Dimitrov, D., Biomechanical Start and Sprinter Acceleration Indicators in Sprint Run. Ed. Krisan. C., 2013.

12.Kasabova, L. and Stoyanov, C., Influence of athletic preparation on the specific qualities of female basketball. 26th International Congress on Physical Education and Sport Science (ICPESS), Komotini, Grece, Abstracts Book icpess.gr. 2018. (https://www.icpes.gr/pics/abstract_9_5_20 18.pdf
13. Kasabova, L. Examination of the special working capacity of students from the profiled basketball groups of the University of National and World Economy Collection "Modern Trends, Problems and Innovations in Physical Education and Sports at Higher Education Institutions", University of National and World Economy, pp. 124-131, 2017.

14.Kirkova, M., The pre-competitive physical training of highly qualified ski-alpine skiers. Dissertation "Doctor" Blagoevgrad, SWU, pp. 44-49, 2019.

15.Kotsev, L. Organization of sports and basketball competitions at HEIs. Dissertation "Doctor", Veliko Tarnovo University, pp. 53-57, 2019.

16.Stoyanov, Hr., Theoretical and methodical aspects of the development of the special musical qualities in the 200 and 400 meter courses. Type-Top Press. S., pp. 13-17, 2016. 